\title{
Influence of temperature and homogenization on honey crystallization
} Influência da temperatura e da homogeneização na cristalização de mel

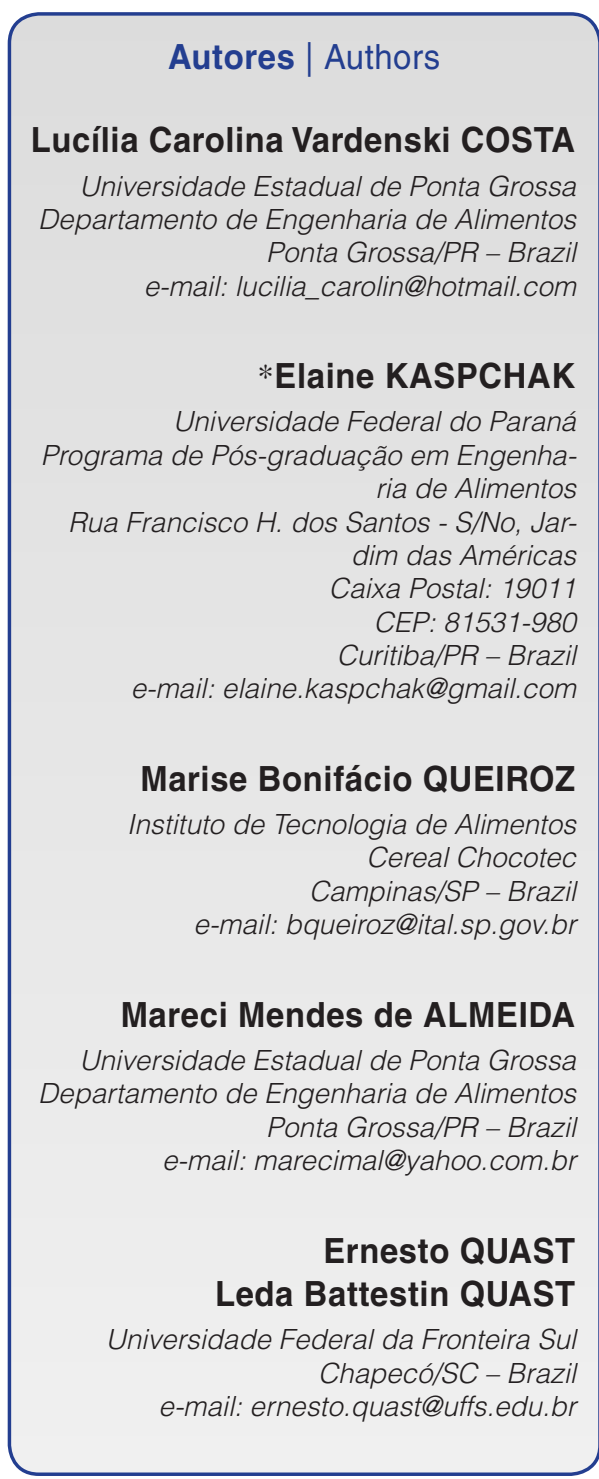

*Autor Correspondente / Corresponding Author

Received: Dec. 2, 2014

Approved: May 12, 2015

\section{Summary}

This work aimed to verify the influence of prior homogenization and storage temperature on the crystallization of honey. Honeys from Campos Gerais, PR Brazil, were used for the experiments. The samples were subjected to homogenization at $0,180,360$ and $540 \mathrm{rpm}$ for 15 minutes and stored at $15^{\circ} \mathrm{C}$ or $25^{\circ} \mathrm{C}$. Crystallization was monitored by the colour, absorbance at $660 \mathrm{~nm}$ and moisture analysis. At the end of the experiment, the crystal sizes were determined by optical microscopy and laser diffraction. It could be observed that the samples kept at $15{ }^{\circ} \mathrm{C}$ and homogenized by agitation at 360 or 540 rpm showed crystal formation after 7 days of storage, while all the samples stored at $25^{\circ} \mathrm{C}$ showed crystal formation after 20 days. It was also observed that the effect of temperature was much more pronounced than that of mechanical agitation during homogenization. All the samples stored at $15^{\circ} \mathrm{C}$ developed crystals that were smaller than $20 \mu \mathrm{m}$.

Key words: Size distribution; Crystals; Honey.

\section{Resumo}

O objetivo deste trabalho foi verificar a influência da homogeneização prévia e da temperatura de armazenamento na cristalização do mel. Mel da região dos Campos Gerais/PR (Brasil) foi usado para os experimentos. As amostras foram submetidas a homogeneização sob agitação de 0, 180, 360 ou 540 rpm por 15 minutos e armazenadas a $15^{\circ} \mathrm{C}$ ou $25^{\circ} \mathrm{C}$. A cristalização foi monitorada por meio de análises de cor, absorbância a $660 \mathrm{~nm}$ e umidade. Ao final dos experimentos, o tamanho dos cristais formados foi determinado por microscopia ótica e difração a laser. Pode-se observar que as amostras mantidas a $15^{\circ} \mathrm{C}$ homogeneizadas sob agitação de 360 e 540 rpm apresentaram formação de cristais após 7 dias de armazenamento, enquanto todas as amostras armazenadas a $25{ }^{\circ} \mathrm{C}$ formaram cristais após 20 dias de armazenamento. Observou-se que a temperatura teve um efeito mais pronunciado na cristalização do que a agitação durante a etapa de homogeneização. Todas as amostras armazenadas a $15^{\circ} \mathrm{C}$ apresentaram cristais menores que $20 \mu \mathrm{m}$.

Palavras-chave: Distribuição de tamanho; Cristais; Mel. 


\section{Introduction}

An understanding of the principles that control the prevention or formation of a crystalline sugar phase is quite important in the development of satisfactory food products. Sugars are present in many foods, varying from naturally occurring products such as honey to formulated foods, including jellies and gels as well as confectionery (HARTEL; SHASTRY, 1991).

Honey is composed mainly of sugars, of which the monosaccharides fructose and glucose are the most abundant (approximately $70-85 \%$ of the honey solids). Furthermore, small quantities of disaccharides (maltose and sucrose), trisaccharides and oligosaccharides are also present (BHANDARI et al., 1999; MORA-ESCOBEDO et al., 2006; LAZARIDOU et al., 2004).

Glucose is the main component that crystallizes in honey because of its existence in the supersaturated state. Bhandari et al. (1999) summarized some methods to avoid the crystallization of honey, including storage at freezing temperatures $\left(-40^{\circ} \mathrm{C}\right)$, thermal treatment for dissolving the crystals at higher temperatures $\left(>45^{\circ} \mathrm{C}\right)$, the addition of inhibitors such as ascorbic and isobutyric acids and the adjustment of the glucose and fructose or water contents (SUBRAMANIAN et al., 2007).

When uncontrolled crystallization occurs during storage, it can lead to phase separation that results in a crystalline phase at the bottom and a dark-coloured supernatant liquid phase, making the honey less attractive to the consumer (GLEITER et al., 2006; ZAMORA; CHIRIFE, 2006). On the other hand, when crystallization occurs in a controlled manner, it is possible to have products such as creamy honey, in which a large number of very small crystals are not perceived during gustation (MORA-ESCOBEDO et al., 2006; SUBRAMANIAN et al., 2007).

The presence or absence of crystals, as well as the number, the average size and the size distribution of these crystals are critical parameters for the development of a desirable texture. The mass transfer caused by shaking can directly influence the relative rate of nucleation and crystal growth, showing that smaller crystals are produced with higher rates of agitation (HARTEL; SHASTRY, 1991).

There are several methods to set the characteristic size of a crystal, corresponding to form factors and size distribution (NÝVLT et al., 2001). Jeffery (1987) highlights some methods for measuring the size of a sugar crystal contained in molten sugar, including optical microscopy, electron microscopy and the laser diffraction method (light scattering).

The aim of this study was to investigate the effect of mechanical stirring and temperature on the formation of a crystalline mass and on the size distribution of the honey crystals.

\section{Material and methods}

Honey from Campos Gerais (PR State, Brazil) was used in the experiments. The physical-chemical characterization was made according to Brazilian law (BRASIL, 2000) as follows: reducing sugars, apparent sucrose, insoluble solids, $\mathrm{pH}$ and acidity (BOGDANOV et al., 1997), hydroxymethylfurfural (HMF) and moisture (HORWITZ, 2000) and the diastasis index (SANTOS et al., 2003). All analyses were carried out in triplicate.

\subsection{Sample preparation}

The honey samples were maintained at $37^{\circ} \mathrm{C}$ in an incubator for one week to ensure complete melting of the honey crystals. After this period, the liquid honey was poured into $500 \mathrm{~mL}$ beakers and submitted to stirring (New Ethics, 10893/08) for 15 minutes at room temperature. The samples subjected to different agitation speeds were transferred to sealed glass jars and stored at 15 or $25^{\circ} \mathrm{C}$. Table 1 shows the stirring conditions and storage temperatures used.

The analyses were accompanied for five weeks, twice a week, taking two samples for each analysis. The temperatures were set based on a previous crystallization study by Kuroishi et al. (2012).

Sample number 9 (control) was not treated and was stored at room temperature and used as the reference for determining the crystal size distribution (CSD).

\subsection{Sample analyses}

Honey crystallization was monitored using colour and absorbance determinations. The color analysis was carried out using a digital colorimeter (HunterLabMiniScan EZ 4500L) on the CIELAB scale $\left(L^{*}, a^{*}\right.$ and $\left.b{ }^{*}\right) . L^{*}$ is the

Table 1. Treatments for honey crystallization.

\begin{tabular}{ccc} 
Samples & $\begin{array}{c}\text { Stirring } \\
(\mathbf{r p m})\end{array}$ & $\begin{array}{c}\text { Storage temperature } \\
\left({ }^{\circ} \mathbf{C}\right)\end{array}$ \\
1 & 0 & 25 \\
2 & 180 & 25 \\
3 & 360 & 25 \\
4 & 540 & 25 \\
5 & 0 & 15 \\
6 & 180 & 15 \\
7 & 360 & 15 \\
8 & 540 & 15 \\
9 & 0 & Room temperature - \\
& & control \\
\hline
\end{tabular}


lightness or brightness component, which varies between 0 and 100 , and $a{ }^{*}$ and $b$ * are two colour components, which vary from -100 to $100\left(a{ }^{*}\right.$ is from green to red and $b$ * is from blue to yellow). The $L$ *, $a$ * and $b$ * values obtained for each sample were converted into the Whiteness Index (WI) according to Briones and Aguilera (2005), cited by Kuroishi et al. (2012), as shown in Equation 1.

$$
W I=100-\left[(100-L *)^{2}+a *^{2}+b *^{2}\right]^{0.5}
$$

The absorbance was obtained at $660 \mathrm{~nm}$ in a UV-visible spectrophotometer (UVMIN - 1240 Shimadzu), as proposed by Lupano (1997). Moisture, colour and absorbance were measured in duplicate approximately every 5 days for 35 days of storage at the two storage temperatures. The final absorbance was compared for all samples by the Tukey analyses using Statistica software.

After 34 days of storage, the crystallized honey was characterized by its crystal size distribution (CSD) using two methods: image analysis generated by optical microscopy and laser diffraction.

The crystal size distribution was appraised by optical microscopy imaging according to Queiroz (2010), with some adaptations. The honey sample was spread on a glass slide and then dispersed in a drop of polyethylene glycol. The measurements were made using an optical microscope (Olympus, model BX41) with polarized light, magnified 200 times. The images were processed electronically using Scion Image Software, measuring the width (a) and diameter (b) of the crystals in micrometers $(\mu \mathrm{m})$. With these measurements, the equivalent diameter (La) was calculated using Equation 2 (NÝVLT et al., 2001).

$$
L a \approx\left(\frac{4 a b}{\pi}\right)^{0.5}
$$

The statistical distribution of the crystals was made in blocks with a gap of $5 \mu \mathrm{m}$ using the La measurement for a population of 300 crystals for each sample.

By Laser Diffraction the crystal size distribution was obtained with a LA-950 Laser Scattering Particle Size Distribution Analyzer (Horiba Instruments, Inc). The sample was prepared by pre-dispersion of a small amount of the crystals in ethylene glycol, then diluting them in absolute ethyl alcohol. The analysis was carried out in duplicate for each sample, five readings being taken for each measurement.

The results for CSD obtained by both methodologies were represented by cumulative distribution.

\section{Results and discussion}

The main tests recommended by the Brazilian legislation for the recognition of heated or adulterated honeys are diastase activity and the presence of hydroxymethylfurfural (HMF). As shown in Table 2 the honey sample used in this study was in accordance with the limits imposed by the law (BRASIL, 2000) for all the physical and chemistry analyses. It was possible to determine the type of honey using the Kirkwood equation (KIRKWOOD et al., 1960, 1961), and it was classified as honeydew.

Azeredo et al. (1999) observed that the moisture present in honey influenced the flavour, density, crystallization, solubility and conservation. In this study, the moisture of the honey, as monitored during storage, remained constant at $18.8 \%$, which is in accordance with Kuroishi et al. (2012) who found an average moisture content of $17.55 \% \pm 0.42$ for honey.

\subsection{Honey crystallization by the absorbance and whiteness index analyses}

Figure 1 shows the absorbance values at $660 \mathrm{~nm}$ for honey samples homogenised at different speeds. The samples were stored at room temperature $\left(25^{\circ} \mathrm{C}\right)$ and $15{ }^{\circ} \mathrm{C}$ for a period of 34 days.

Table 2. Results of the physical and chemical analyses of the honey.

\begin{tabular}{|cc|}
\hline Analysis & Results \\
\hline Moisture (\%) & $18.8 \pm 0.0$ \\
Reducing sugars (\%) & $73.3 \pm 2.9$ \\
Apparent sucrose (\%) & $8.6 \pm 1.6$ \\
Insoluble solids (\%) & $0.49 \pm 0.09$ \\
Ash (\%) & $0.32 \pm 0.02$ \\
Acidity (mEq/kg) & $26.4 \pm 2.2$ \\
Diastasis Index (Göthe) & $15.1 \pm 1.60$ \\
Hydroxymethylfurfural (mg/kg) & $31.0 \pm 0.2$ \\
pH & $4.06 \pm 0.02$ \\
\hline
\end{tabular}

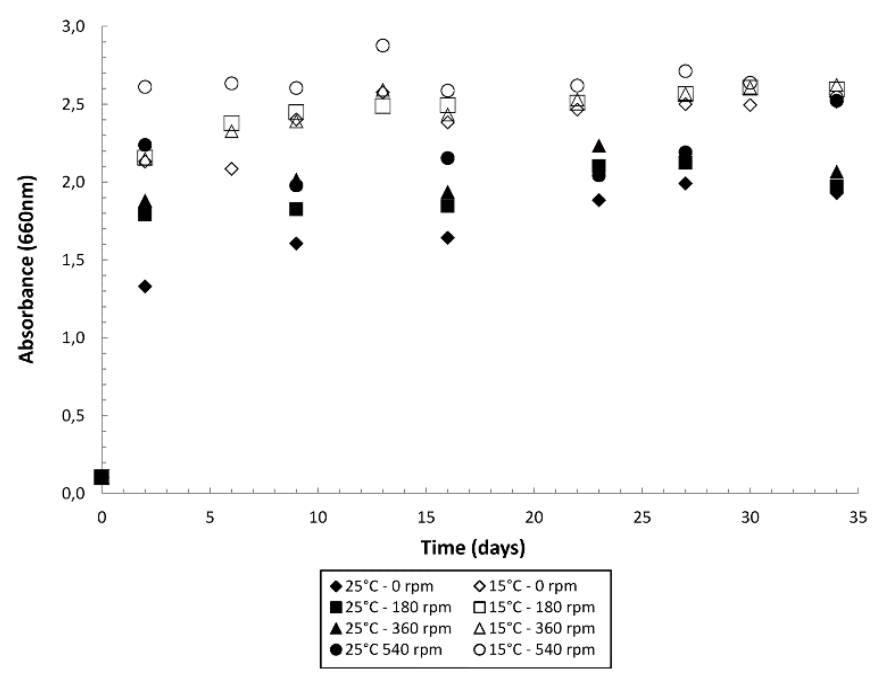

Figure 1. Variation in absorbance during the storage of honey at $15^{\circ} \mathrm{C}$ and $25^{\circ} \mathrm{C}$. 
The colour of honey can easily change from light (crystallized honey) to dark brown (heated or non-crystallized honey) (TOSI et al., 2004), which can be visualized by its absorbance. At the temperature of $25^{\circ} \mathrm{C}$, the maximum absorbance values did not exceed 2.5 during the 34 days of storage. However, practically all the samples stored at $15^{\circ} \mathrm{C}$ had absorbance values greater than 2.5 after 15 days of storage. This indicated that crystallization was more intense at $15^{\circ} \mathrm{C}$ as noted by the opacity caused by the formation of glucose crystals. The turbidity of honey increases with crystallization, and the increase in absorbance at $660 \mathrm{~nm}$ may be regarded as indicative of crystallization.

An analysis of the absorbance results by the Tukey test at a 95\% confidence level, showed that all the samples stored at $15^{\circ} \mathrm{C}$ had statistically similar absorbance values, independent of the agitation used. In addition, after 34 days of storage, the sample maintained at $25^{\circ} \mathrm{C}$ and stirred at $540 \mathrm{rpm}$ showed an absorbance value similar to those stored at $15^{\circ} \mathrm{C}$. This may indicate that agitation has an influence on crystallization at $25^{\circ} \mathrm{C}$.

Lupano (1997) found maximum absorbance values close to 3 for honey stored for 40 days at $10^{\circ} \mathrm{C}$ and $4^{\circ} \mathrm{C}$, and maximum absorbance values near 1.5 for honey stored for 40 days at $20^{\circ} \mathrm{C}$.

Using a visual analysis of the samples stored at 15 and $25^{\circ} \mathrm{C}$, it could be seen that those homogenized at $360 \mathrm{rpm}$ and $540 \mathrm{rpm}$ and stored at $15^{\circ} \mathrm{C}$ showed crystal formation after 7 days of storage, while samples stored at $25^{\circ} \mathrm{C}$ showed crystal formation after 20 days. In the samples stored at $25^{\circ} \mathrm{C}$ and in sample number 9 (control), a supernatant appeared, which did not occur in the samples stored at $15^{\circ} \mathrm{C}$. This formation of a supernatant is a characteristic of slow crystal formation, and a large mass of crystals tend to settle at the bottom of the flask due to gravitational forces.

Figure 2 shows the results obtained for the Whiteness Index (WI) of the honey stored at $15^{\circ} \mathrm{C}$ and $25^{\circ} \mathrm{C}$, during 34 days of storage.

It can be seen in Figure 2 that the samples stored at $25^{\circ} \mathrm{C}$ presented more oscillations in the Whiteness Index, indicating no defined behaviour, probably because of phase separation. For the samples stored at $15^{\circ} \mathrm{C}$, this index tended to increase from 29.8 to 49 after 34 days of storage.

The Whiteness Indexes (WI) of the samples stored at $15^{\circ} \mathrm{C}$ were higher than those of samples stored at $25^{\circ} \mathrm{C}$. With respect to homogenization, it was observed that the WI values of samples stirred at 0, 180, 360 and $540 \mathrm{rpm}$ showed similar behaviours during storage, reinforcing the idea that the temperature was the main cause of opacity in the samples. Kuroishi et al. (2012) reported that the Whiteness Index remained constant for honey samples stored at $31^{\circ} \mathrm{C}$, and no crystallization was observed in these samples during 3 weeks of storage.
The authors also reported a trend for the Whiteness Index to increase in samples stored for 3 weeks at temperatures of $11^{\circ} \mathrm{C}$ and $21^{\circ} \mathrm{C}$, this increase being due to the formation of crystals in the honey. These results reinforce the use of the Whiteness Index as an indication of the presence of crystals in honey samples.

\subsection{Distribution of crystal size as a function of temperature and agitation}

The rate of crystal growth or grain size distribution, and the shape of the crystals depend on the composition of the honey and the storage temperature (SERRA BONHEVI, 1989).

Figure 3 shows the results obtained for the crystal size distribution by optical microscopy for all the experiments carried out. It was observed that the temperature had a greater effect on crystal size distribution

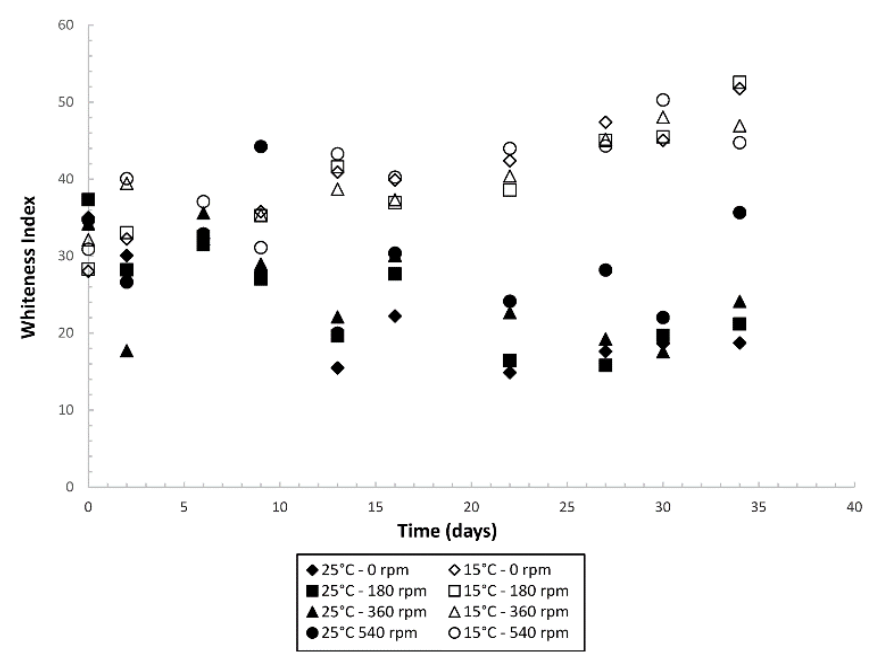

Figure 2. Values obtained for the Whiteness index at $15^{\circ} \mathrm{C}$ and $25^{\circ} \mathrm{C}$ during storage of the honey.

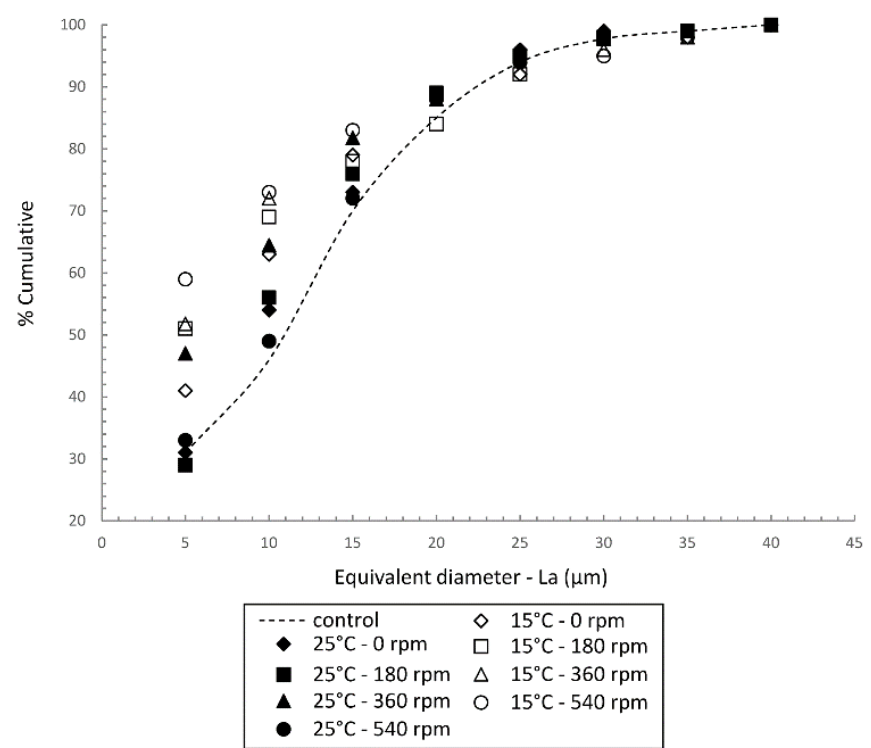

Figure 3. Cumulative distribution obtained by optical microscopy of the crystal size of the honey samples. 
than the stirring applied during homogenization. There were more smaller crystals in the sample stored at $15^{\circ} \mathrm{C}$ than in the sample stored at $25^{\circ} \mathrm{C}$. Homogenization speeds of 180,360 and $540 \mathrm{rpm}$ before storage at $15^{\circ} \mathrm{C}$ showed similar results for crystal size distribution.

Hartel and Shastry (1991) disclosed that, in general, there was an optimum temperature for crystallization, at which the nucleation rate was maximal and many small crystals could be formed. This optimum temperature depends on many factors, but mainly on the product composition, the cooling rate and the level of agitation before storage.

Flink (1983) noted that when the temperature decreased, the sugar solubility also decreased, promoting crystallization. On the other hand, Johnson et al. (1975) concluded that with decreasing temperature, the viscosity increased, slowing down the mobility of the molecules and resulting in a lower rate of crystal growth.

In a study of temperatures from $2^{\circ} \mathrm{C}$ to $40^{\circ} \mathrm{C}$, Sopade et al. (2003) observed a decrease in viscosity with increasing temperature for the samples of honey. The authors also observed a more pronounced decrease in viscosity from $25^{\circ} \mathrm{C}$ to $30^{\circ} \mathrm{C}$, and less pronounced above $35^{\circ} \mathrm{C}$. Thus, the viscosity of honey stored at $25^{\circ} \mathrm{C}$ is lower than that of honey stored at $15^{\circ} \mathrm{C}$, and the greater mobility of the molecules favours crystal growth. However, as said earlier, the solubility of the sugar increases with increasing temperature, which may explain the rate of granulation/slow growth observed at $25^{\circ} \mathrm{C}$ and the formation of larger sized crystals.

According to White (1974), the crystallization of honey is accelerated between $13^{\circ} \mathrm{C}$ and $15.5^{\circ} \mathrm{C}$ and delayed at freezing temperatures. Lupano (1997) noted that crystallized honey stored at $10^{\circ} \mathrm{C}$ had a less sandy appearance than honey stored at $20^{\circ} \mathrm{C}$ (which showed grainy crystals of various sizes).

The control sample showed a lower amount of crystals smaller than or equal to $5 \mu \mathrm{m}$, similar to non-homogenized samples or those homogenized at $180 \mathrm{rpm}$ and stored at $25^{\circ} \mathrm{C}$. These results indicate that the storage of honey at a constant temperature of $25^{\circ} \mathrm{C}$ without agitation was not efficient for the formation of small crystals.

According to the studies of Bhandari and Bareyre (2003) and Bakier (2003), it is possible to correlate the formation of smaller crystals in the samples at $15^{\circ} \mathrm{C}$, rather than at $25^{\circ} \mathrm{C}$, with no formation of supernatant. In samples stored at $15^{\circ} \mathrm{C}$, the glucose crystals were smaller resulting in a greater contact surface which could interact with a larger number of water molecules, without the formation of a supernatant as observed in the samples stored at $25^{\circ} \mathrm{C}$.

The results for crystal size distribution obtained by laser diffraction are shown in Figure 4.

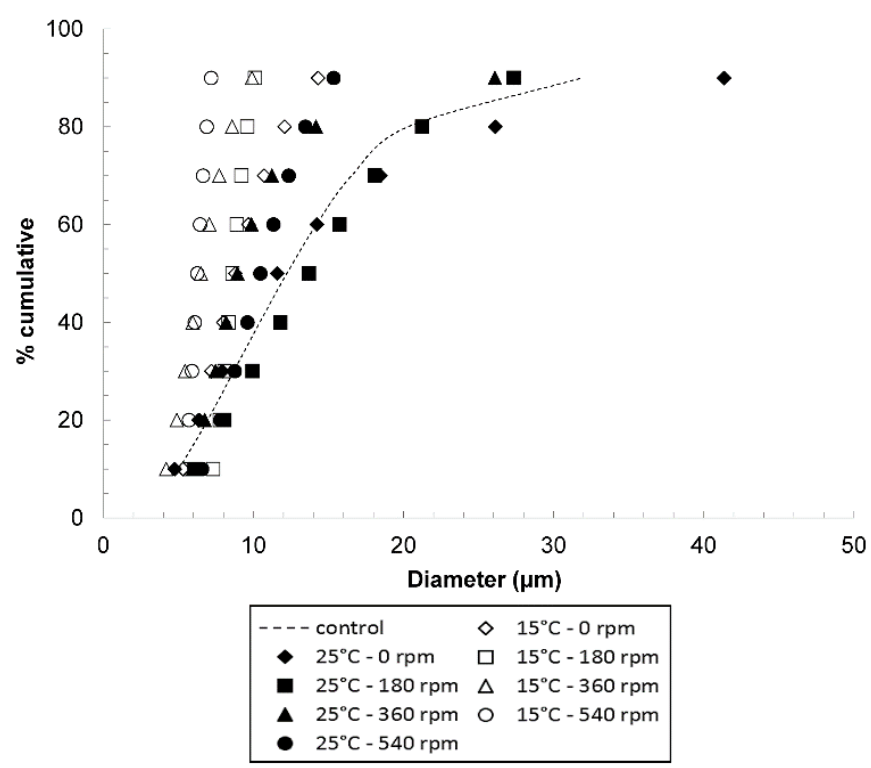

Figure 4. Crystal size distribution as obtained by laser diffraction of samples stirred at different speeds and stored at $15^{\circ} \mathrm{C}$ or $25^{\circ} \mathrm{C}$.

To date, the use of the laser diffraction method to determine the crystal size distribution cannot be found in the technical literature. Figure 4 shows the formation of smaller crystals in the treatments at $15^{\circ} \mathrm{C}$ as compared to those treated at $25^{\circ} \mathrm{C}$, which was similar to the results obtained using optical microscopy.

A temperature of $15^{\circ} \mathrm{C}$ was shown to be critical for accelerating crystallization, forming smaller crystals of below $20 \mu \mathrm{m}$ for the four homogenization speeds used. However, the increase in intensity of the homogenization speed showed a directly proportional effect with the decrease in crystal size.

The mobility of glucose is higher at $25^{\circ} \mathrm{C}$ due to the lower viscosity of the system, and the tendency to form a smaller amount of larger sized crystals was observed from the results of the crystal size distribution. The effect of stirring speed during homogenization was directly proportional to the decrease in size, but only the sample stored at $25^{\circ} \mathrm{C}$ and homogenized at $540 \mathrm{rpm}$ produced more than $90 \%$ of crystals below $20 \mu \mathrm{m}$ at this temperature, indicating that storage near ambient temperature promoted the formation of larger crystals.

A reduction in crystal size at a temperature of $25^{\circ} \mathrm{C}$ was only possible with the highest homogenization speed. This is because stirring before storage distributes the particles of impurities inside the mass of honey, which serve as nuclei for crystal formation.

\section{Conclusion}

At the end of the experiments all the samples stored at $15^{\circ} \mathrm{C}$ were uniform and fully crystallized but in the samples stored at $25^{\circ} \mathrm{C}$, less than half the volumes were crystallized. An influence of temperature and 
Influence of temperature and homogenization on honey crystallization

COSTA, L. C. V. et al.

homogenization was observed, especially in relation to the crystal size distribution, where smaller crystals were associated with better crystallization characteristics. None of the samples crystallized at $15^{\circ} \mathrm{C}$ showed crystals larger than $20 \mu \mathrm{m}$, and of the samples stored at $25^{\circ} \mathrm{C}$ only the one homogenized at $540 \mathrm{rpm}$ showed a distribution similr to that of the samples stored at $15^{\circ} \mathrm{C}$, since the initial distribution of the impurities was more homogeneous.

\section{Acknowledgements}

The authors are grateful to CNPq for their financial support: Process 478936/2010-9.

\section{References}

AZEREDO, M. A. A.; AZEREDO, L. C.; DAMASCENO, J. G. Características físico-químicas do mel no município de São Fidélis - RJ. Ciência e Tecnologia de Alimentos, Campinas, v. 19, n. 1,1999

BAKIER, S. Grain size characteristics of the solid phase occuring at honey granulation. Inzynieria Rolnicza, Kraków, v. 7, n. 49, p. 5-10, 2003.

BHANDARI, B.; BAREYRE, I. Estimation of crystalline phase present in the glucose crystal-solution mixture by water activity measurement. LWT - Lebensmittel-Wissenschaft und-Technolgie, Munique, v. 36, n. 7, p. 729-733, 2003. http:// dx.doi.org/10.1016/S0023-6438(03)00086-0.

BHANDARI, B.; D'ARCY, B.; CHOW, S. Rheology of selected Australian honeys. Journal of Food Engineering, Pullman, v. 41 , n. 1, p. 65-68, 1999. http://dx.doi.org/10.1016/S02608774(99)00078-3.

BOGDANOV, S.; MARTIN, P.; LÜLLMANN, C. Harmonised methods of the European Honey Comission. Apidologie, Paris, p. 1-59, 1997. Extra issue.

BRASIL. Ministério da Agricultura, Pecuária e Abastecimento. Instrução normativa $n^{\circ} 11$, de 20 de outubro de 2000. Regulamento Técnico de identidade e qualidade do mel. Diário Oficial [da] República Federativa do Brasil, Brasília, DF, 20 Oct. 2000. Available at: <http://extranet.agricultura.gov.br/ sislegis-consulta/consultarLegislacao.do?operacao=visualiza r\&id=7797 >. Accessed on: 04 Mar. 2012.

BRIONES, V.; AGUILERA, J. M. Image analysis of changes in surface colour of chocolate. Food Research International, Barking, v. 38, n. 1, p. 87-94, 2005. http://dx.doi.org/10.1016/j. foodres.2004.09.002

FLINK, J. M. Structure and structure transitions in dried carbohydrate materials. In: PELEGAND, M.; BAGLEY (Ed.). Physical properties of foods. Westport: Springer, 1983. p. 473-521.

GLEITER, R. A.; HORN, H.; ISENGARD, H. D. Influence of type and state of crystallization on the water activity of honey. Food
Chemistry, London, v. 96, n. 3, p. 441-445, 2006. http://dx.doi. org/10.1016/j.foodchem.2005.03.051.

HARTEL, R. W.; SHASTRY, A. V. Sugar crystallization in food products. Critical Reviews in Food Science and Nutrition, London, v. 30, n. 1, p. 49-112, 1991. http://dx.doi. org/10.1080/10408399109527541. PMid:1930682.

HORWITZ, W. (Ed.). Official Methods of Analysis of the Association of Official Analytical Chemists. 17th ed. Gaithersburg: AOAC, 2000. chap. 44, p. 22-33.

JEFFERY, M. S. Particle size technology of fondant. In: PARTICLE SIZE TECHNICAL SEMINAR, 41., 1987, Pennsylvania. Anais... Pennsylvania: PMCA, 1987. p. 23-25. Available at: <http://www. pmca.com/firstpage/1987_07.pdf>. Accessed on: 04 Mar. 2012.

JOHNSON, J. F.; MARTIN, J. R.; PORTER, R. S. Determination of viscosity of food systems. In: RHA, C. K. (Ed.). Theory, determination and control of physical properties of food materials. Netherlands: Springer, 1975. p. 25-38.

KIRKWOOD, K. C.; MITCHELL, T. J.; SMITH, D. Examination of the occurrence of honeydew in honey. Analyst, London, v. 85, n. 1011 , p. $412-416,1960$. http://dx.doi.org/10.1039/ an9608500412.

KIRKWOOD, K. C.; MITCHELL, T. J.; ROSS, I. C. Examination of the occurrence of honeydew in honey. Part II. Analyst, London, v. 86, n. 1020 , p. 164-165, 1961. http://dx.doi.org/10.1039/ an9618600164.

KUROISHI, A. M.; QUEIROZ, M. B.; ALMEIDA, M. M.; QUAST, L. B. Avaliação da cristalização de mel utilizando parâmetros de cor e atividade de água. Brazilian Journal of Food Technology, Campinas, v. 15, n. 1, p. 84-91, 2012. http://dx.doi.org/10.1590/ S1981-67232012000100009.

LAZARIDOU, A.; BILIADERIS, C. G.; BACANDRITSOS, N.; SABATINI, A. G. Composition, thermal and rheological behavior of selected Greek honeys. Journal of Food Engineering, Essex, v. 64, n. 1, p. 9-21, 2004. http://dx.doi.org/10.1016/j. jfoodeng.2003.09.007.

LUPANO, C. E. DSC study of honey granulation stored at various temperatures. Food Research International, Barking, v. 30, n. 9, p. 683-688, 1997. http://dx.doi.org/10.1016/S09639969(98)00030-1.

MORA-ESCOBEDO, R.; MOGUEL-ORDÓÑEZ, Y.; JARAMILLOFLORES, M. E.; GUTIÉRREZ-LÓPEZ, G. F. The composition, rheological and thermal properties of Tajonal (Vigueira dentata) Mexican honey. International Journal of Food Properties, London, v. 9, n. 2, p. 299-316, 2006. http://dx.doi. org/10.1080/10942910600596159>.

NÝVLT, J.; HOSTOMSKÝ, J.; GIULIETTI, M. Cristalização. São Carlos: Editora da UFSCar;IPT, 2001. 160 p.

QUEIROZ, M. B. Estudo da cristalização de fondants formulados com xarope de glicose obtido da fécula da 
Influence of temperature and homogenization on honey crystallization

COSTA, L. C. V. et al.

mandioca. 2010. 144 f. Tese (Doutorado em Engenharia Química) - Faculdade de Engenharia Química, Universidade Estadual de Campinas, Campinas, 2010.

SANTOS, K. S.; MALASPINA, O.; PALMA, M. S. Cinética da diástase em méis de diferentes origens florais. Um novo protocolo experimental. Mensagem Doce, São Paulo, n. 70, p. 2-4, 2003

SERRA BONHEVI, J. Estúdio de la validez de lo sõndices que predicen la cristalizacion de la miel. Revista Agronomica y Tecnologia de los Alimentos, La Rioja, v. 29, p. 47-62, 1989.

SOPADE, P. A.; HALLEY, P.; BHANDARI, B.; D'ARCY, B.; DOBLER, C.; CAFFIN, N. Application of the Willians-Landel-Ferry model to the viscosity-temperature relationship of Australian honeys. Journal of Food Engineering, Oxford, v. 56, n. 1, p. 67-75, 2003. http://dx.doi.org/10.1016/S0260-8774(02)00149-8.
SUBRAMANIAN, R.; HEBBAR, H. U.; RASTOGI, N. K. Processing of honey: a review. International Journal of Food Properties, New York, v. 10, n. 1, p. 127-143, 2007. http://dx.doi. org/10.1080/10942910600981708.

TOSI, E. A.; RÉ, E.; LUCERO, H.; BULACIO, L. Effect of honey high-temperature short-time heating on parameters related to quality, crystallization phenomena and fungal inhibition. LWT Lebensmittel-Wissenschaft und-Technolgie, Munique, v. 37, n. 6, p. 669-678, 2004. http://dx.doi.org/10.1016/j.Iwt.2004.02.005. WHITE, J. W. Beekeeping: honey and honey products. In: JOHSON, A. H.; PETERSON, M. S. (Ed.). Encyclopedia of food technology. Westport: Avi Publishing, 1974. p. 103-108. (v. 2).

ZAMORA, M. C.; CHIRIFE, J. Determination of water activity change due to crystallization in honeys from Argentina. Food Control, Guildford, v. 17, n. 1, p. 59-64, 2006. http://dx.doi. org/10.1016/j.foodcont.2004.09.003. 